\title{
RELATIONSHIP BETWEEN HUSBAND SUPPORT AND PREGNANCY CONTROL IN PREGNANT WOMEN SUKAWENING PUSKESMAS GARUT
}

\author{
Lilis Mamuroh ${ }^{1}$, Sukmawati $^{2}$, Furkon Nurhakim ${ }^{3}$ \\ ${ }^{1}$ Universitas Padjadjaran PSDKU Garut \\ Correspondance: lilis.mamuroh65@gmail.com
}

\begin{abstract}
Data from the Garut District Health Office in 2016 showed that the number of pregnant women was 62,514. 62,818 pregnant women had 1 pregnancy check-up (K1), and only 58,594 pregnant women had 4 pregnancy check-up (K4) (Garut District Health Profile 2016). In the Health profile of Garut Regency, K4 coverage in the Sukawening Health Center area was $92.3 \%$, public health center in Garut with the lowest K4 coverage, and $40 \%$ of pregnant women coming to health services alone, not accompanied by their husbands. Husband's support is one of the reinforcing factors and influences the pregnancy process, but information about the husband's support and its relationship with pregnancy control is still limited. The aim of the study was to determine the relationship of the husband's support to pregnant women with antenatal care (ANC) visits at Sukawening Health Center in 2016. The research method used in this study was descriptive correlational using a cross-sectional approach. Samples were selected using purposive sampling technique, 75 pregnant women were the respondents. Data collection used primary and secondary data with a measuring instrument was a note in the KIA book to find out the ANC frequency, and for husband's support used a questionnaire. Analysis of univariate data in the form of percentage and bivariate analysis with the chi-square test. The results showed that husband's support was $66.7 \%$ support and antenatal care visits were $60 \%$ completed. The analysis result of the relationship between the husband's support to pregnant women with antenatal care visits (ANC) obtained p-value $=0.012$ and $\mathrm{OR}=3.5$. The conclusion is that there is a significant relationship between the husband's support for pregnant women and antenatal care (ANC) visits. Suggestions, health workers at Sukawening Health Center improve health services, especially antenatal care and involve husbands at each visit.
\end{abstract}

Keywords: Antenatal care, husband's support, ANC visit.

\section{INTRODUCTION}

The factors that influence the visit of pregnant women to health services are the Predisposing Factor, namely knowledge and attitudes, Enabling Factor namely distance, location, cost, service facilities, and Reinforcing Factors namely health worker behaviors, family support, service staff and community leader attitudes (Notoatmojo 2005).

Husband support to pregnant women is expected to support the psychological condition of pregnant women and women felt easier accepting physical changes and also control the emotional changes that occur during pregnancy. Well, husband support includes emotional support and instrumental support. Good support from families, especially husbands, to pregnant women fosters mutual trust between family members (husbands) and pregnant women. A good relationship prevents anxiety that might affect the physical and psychological aspects of the mother and fetus (Safarino, 2003).

Data from the Garut District Health Office in 2016 showed the number of pregnant women was 62,514. 62,818 pregnant women had 1 pregnancy checkup (K1), and only 58,594 
pregnant women had 4 pregnancy checkup (K4) (Garut District Health Profile 2016). K4 coverage data in the Sukawening region according to the Health profile of Garut Regency are Sukawening Health Center 92.3\%, Sukamukti Health Center 94.8\%, and Maripari Health Center $96.5 \%$. From these data shows that the Sukawening Health Center is a health center with the lowest K4 coverage.

Research conducted by Retnowati (2007) stated that as many as $61.9 \%$ of pregnant women who were supported by their husbands have high motivation for ANC examinations. An ANC research was conducted by Nurul Hidayati (2008) showed that the husband's participation in pregnancy care is influenced by the husband's level of knowledge. Based on this phenomenon, the researchers were interested in knowing the relationship of a husband's support to pregnant women with antenatal care visits (ANC).

\section{METHODS}

The research method used was descriptive correlational using a cross-sectional approach. This approach included collecting data and then analyzing the relationship of factors to the phenomenon that was happening. The use of this method was to determine the relationship between the husband's support to pregnant women and antenatal care (ANC) visits at the Sukawening Garut Health Center. The sample in this study was selected by purposive sampling technique, and 75 pregnant women participated in this study.

Data were arranged in tabulation form, then analyzed according to data categories in each research variable, namely the independent variable and the dependent variable. To facilitate data processing, SPSS software and Microsoft Excel were used.

\section{RESULTS}

The results of this study are explained in 3 tables namely husband's support (table 1), antenatal visits (table 2), and husband's support relations with ANC visits (Table 3)

1. Husband's Support

Table 1 Husband's Support to Pregnant Women

\begin{tabular}{cccc}
\hline No & Husband's support & Frequency & $\%$ \\
\hline 1. & No & 25 & 33,3 \\
2. & Yes & 50 & 66,7 \\
\hline \multicolumn{2}{c}{ Total } & 75 & 100 \\
\hline
\end{tabular}


Based on table 1, the majority of husbands supported pregnant women $66.7 \%(\mathrm{n}=50)$ for antenatal care at Sukawening Garut Health Center

2. Antenatal Visits

Table 2 Pregnant Women Antenatal Visits

\begin{tabular}{cccc}
\hline No & Antenatal care visits & Frequency & $\%$ \\
\hline 1. & Incomplete $(<4$ kali $)$ & 30 & 40 \\
2. & Complete $(\geq 4$ kali $)$ & 45 & 60 \\
\hline & Total & 75 & 100 \\
\hline
\end{tabular}

Based on table 2, it is discovered that most pregnant women (60\%) visited antenatal care (ANC) according to the government's recommendations which were at least 4 visits to health services when pregnant.

3. Husband's support relations with ANC visits

Table 3 The relationship between the husband's support to pregnant women and Antenatal Care visit

\begin{tabular}{|c|c|c|c|c|c|c|c|c|}
\hline \multirow[t]{3}{*}{$\begin{array}{l}\text { Husband's } \\
\text { support }\end{array}$} & \multicolumn{4}{|c|}{$\begin{array}{c}\text { Antenatal Care (ANC) } \\
\text { visit }\end{array}$} & \multirow{2}{*}{\multicolumn{2}{|c|}{ Total }} & \multirow[t]{3}{*}{$\begin{array}{c}P \\
\text { value }\end{array}$} & \multirow[t]{3}{*}{$\begin{array}{c}\text { OR } \\
(95 \% \mathrm{CI})\end{array}$} \\
\hline & \multicolumn{2}{|c|}{ Incomplete } & \multicolumn{2}{|c|}{ Complete } & & & & \\
\hline & $\mathrm{F}$ & $\%$ & $\mathrm{~F}$ & $\%$ & $\mathrm{~F}$ & $\%$ & & \\
\hline No & 15 & 60 & 10 & 40 & 25 & 100 & 0,012 & 3,5 \\
\hline Yes & 15 & 30 & 35 & 70 & 50 & 100 & & \\
\hline Total & 30 & 40 & 45 & 60 & 75 & 100 & & \\
\hline
\end{tabular}

Table 3 showed that the bivariate test found $\mathrm{p}$-value $=0.012$, meaning that there was a significant relationship between the husband's support and antenatal care visits at Sukawening Garut health center. OR-3.5 means that respondents who did not get husband's support had a chance of 3.5 times not doing antenatal care visits compared with respondents who were supported.

\section{DISCUSSION}

The results of this study indicated that most husbands supported pregnant women to performed ANC, most pregnant women performed pregnancy checks for 4 or more times, and obtained a significant p-value, meaning there is a relationship between 
husband's support for pregnant women and antenatal care visits. The results also showed that respondents who did not get husband's support had a greater chance of not performing antenatal care visits compared to respondents who were motivated.

Husband support is a psychosocial aspect that can provide emotional strength to pregnant women. Family affection, especially husband and desire to get offspring is very helpful in antenatal care, childbirth, and finished with family happiness. But unlike the unwanted pregnancy and no support from husband would cause things such as excessive pregnancy complaints, psychological imbalances facing pregnancy and childbirth, abortion, and divorce after childbirth, because the marriage was forced. That is why the husband's support is very important so that mothers do not feel afraid of facing pregnancy and childbirth (Manuaba 2006).

The husband has a very important role in maintaining and improving the health of family members and the community as well as helping the success of health services. As reported by (Marby 1964 in Andra 2007), that husbands as the family have influence in various health service actions carried out including prevention, treatment, and care for family members. This is in accordance with Nurul Hidayati (2008) study which showed that the husband's participation in pregnancy care is influenced by the husband's level of knowledge about pregnancy. Other research discovered that husbands' social support is highly expected by wives, such as husbands who crave babies in wives, husbands show happiness after childbirth, pay attention to their health, accompany and understand their wives, do not hurt their wives, pray for their salvation, and accompany them when wife in labor (Harymawan, 2007).

The role of the family, especially the husband, is very important for a pregnant woman. The involvement and support given by the husband to pregnancy will strengthen the relationship between father, child and husband, and wife. Support obtained by pregnant women would make her more calm and comfortable in her pregnancy. This will give a healthy pregnancy. Support provided by husbands, for example, by sending mothers to have their pregnancies checked, fulfilling the mother's wishes, reminding them to take Fe tablets, and helping with household activities while pregnancy. Although husbands seem to do small things but have a high meaning in improving women's psychological health. 


\section{CONCLUSION}

The conclusion is that there was a significant relationship between the husband's support for pregnant women with antenatal care (ANC) visits. The results of this study are expected to be a reference in improving the quality of health services related to the support of husbands who have pregnant wives to better understand the importance of participation or support in prenatal care.

\section{REFERENCES}

Arikunto,Suharsimi. 2005. Manajemen penelitian. Revisi ketujuh. Jakarta: Rineka cipta

BKKBN. 2001). /Panduan Antenatal Care./ Jakarta : BKKBN (diakses pada tanggal 10 April 2013), diunduh dari http://.depkes.go.id Depkes RI. (2008).

Chandra,Budiman.2008.Metodologi Penelitian Kesehatan.Jakarta:EGC

Friedma, Marlyn M, 2003, Keperawatan Keluarga Teori Dan Praktik edisi 3. Jakarta. EGC

Harymawan, 2007, Dukungan Suami dan Keluarga, http://www.infowikipedia.com. diakses pada tanggal 12 April 2013

Henderson, C. 2006. Buku Ajar Konsep Kebidanan. Jakarta: EGC

Hidayat ,A.Azimul Alimul.2006.Metodelogi Penelitian Kebidanan dan Teknik Analisis Data.Jakarta: Salemba Medika

Manuaba. 2008. Ilmu Kebidanan, Kandungan dan KB. Jakarta : EGC

Meilani, Niken dkk. 2009. Kebidanan Komunitas. Yogyakarta : Fitramaya.

Nadesul, H. 2006. Buku Sehat Calon Pengantin dan Keluarga muda. Jakarta: buku Kompas

Notoatmodjo, Soekidjo.2002. Metodologi Penelitian Kesehatan. Jakarta : Rineka Cipta 2005 Pendidikan Dan Prilaku Kesehatan.Jakarta : Rineka Cipta

2010. Ilmu Perilaku Kesehatan. Jakarta: Rineka Cipta

Nurul. H. 2008. Hubungan Tingkat Pengetahuan Suami dengan Partisipasi Suami dalam Asuhan kehamilan di Puskesmas 1 Toroh Kabupaten Grobogan Surakarta. http://www.skripsi-KTI.com.diakses pada tanggal 10 April 2013 
Prawirohardjo, S. 2006. Ilmu Kebidanan. Jakarta: Yayasan Bina Pustaka Sarwono Prawirodihardjo

Retnowati. 2007. Hubungan Antara Dukungan Suami Terhadap Motivasi ibu dalam Memeriksakan Kehamilan di Puskesmas Bathi Dolopo Madiun Jawa Timur.), diunduh dari http://www.skripsi-KTI.com.diakses pada tanggal 12 April 2013.

Safarino. 2003. Dukungan suami. Jakarta : Salemba Medika. http://www.worpress.com. diakses pada tanggal 12 April 2013

Saifudin. 2002. Buku Acuan Pelayanan Kesehatan Maternal dan Neonatal. /Yogyakarta : Yayasan Bina Pustaka Pustaka Sarwono Prawirohardjo. http ://www.Kesmas- unsoed.blogspot.com. diakses pada tanggal 10 April 2013

Suhita.2005. psikologi wanita. Jakarta: Pustaka Hidayat www.library.upnvj.ac.id/pdf/3keperawatanpdf/0910712015/dafpus.pdf $\quad$ diakses tanggal 10 April 2013 